\title{
Breaking the 'Silence' of the Military Regime: New Politics of Memory in Brazil
}

\author{
NINA SCHNEIDER \\ University of Essex, UK and FernUniversität Hagen, Germany
}

\begin{abstract}
This article elucidates the latest developments in the 'politics of memory' regarding the military regime in Brazil. Only recently, I argue, has the Brazilian state abandoned its 'politics of silence' and started to actively champion the memory of the left-wing 'resistance'. This new strategy climaxed in a governmental crisis over a historic plan to establish a National Truth Commission to investigate human rights violations during the military regime. The article analyses key incidents and debates prior to the crisis, and contrasts the post-dictatorial collective memory of Brazil with that of other Latin American countries.
\end{abstract}

Keywords: memory, military regime, Brazil, Memórias Reveladas, amnesty, truth commission.

Four resignations at a single sweep. This was how the Defence Minister, Nelson Jobim, and three leading military officials reacted to a proposal signed by the Brazilian President, Luiz Inácio Lula da Silva, on 21 December 2009: the third National Program of Human Rights or PNDH-3 (Éboli, 2009; Agência Brasil, 2010). The program's key proposal is the creation of a National Truth Commission to investigate human rights violations committed during the military regime in Brazil (1964-1985). PNDH-3 was created by Minister Paulo Vannuchi, leader of the Special Ministry for Human Rights (Secretaria Especial dos Direitos Humanos; SEDH) since 2005 (Aquino, 2009). According to Vannuchi's proposal, the Truth Commission will be responsible for: the request of private and public documents; the reconstruction of cases of human rights abuses; the locating of dead bodies; a public information policy about the structures of violence; and the clarification of the practice of torture (Agência Brasil, 2010). The official news agency, Agência Brasil (2010), claims that the main reason for Defence Minister Jobim's and the three highest military officials' rejection of the plan is their fear of a possible revocation of the 1979 Amnesty Law that currently grants full amnesty to military officials involved in human rights violations and militant opponents of the regime alike. They interpret the original proposal as a direct attack on the armed forces. Vannuchi tried to ease the situation declaring that the Truth Commission was actually in favour of the military, as it demonstrated that the armed forces could not be compared to half a dozen torturers (Lima, 2010). Reconciliation, Vannuchi argued, should not mean covering up the past, and forcing thousands of military officials to defend those 
who committed crimes against humanity (Lima, 2010). Vannuchi has enjoyed support from the President of the Ordem dos Advogados (OAB; Brazilian Lawyers Association), Cezar Britto, who criticised Jobim and the generals for putting pressure on President Lula (Lima, 2009). Eventually, President Lula promised to amend the proposal-a defeat for the Minister of Human Rights.

These frictions within the government reflect the extent to which Brazil is still trying to come to terms with the legacy of its military past, although it is still lagging far behind other South American countries in relation to public remembering and the prosecution of human rights perpetrators. In no other Latin American country has collective denial of the military past been as acute as in Brazil, where memory has been largely reduced to the private remembrance of families affected by torture and murder who have been supported by the Catholic Church, lawyers and human rights activists (Coimbra, 2001: 12; Santos, Teles and Teles, 2009). I use the term 'memory' in a broad sense referring to the remembering of historical events in the form of material objects and social practices in the public as well as the private sphere. Recent events and debates indicate a new phase in Brazilian collective memory: sectors of the state have undergone a significant shift from a 'politics of silence' to a 'politics of memory' in honour of left-wing opposition groups who suffered torture and death, the most visible manifestation being the proposal for a Truth Commission. These new 'politics of memory' have faced fierce opposition from some quarters, climaxing in the recent struggles about the Amnesty Law and the National Truth Commission. This article analyses the development of the state's 'politics of memory', which led to the current crisis, taking the 1979 Amnesty Law as a starting point, and highlights the major incidents and debates along the way. It provides an overview of the Brazilian culture of memory as distinct from that of other Latin American countries, particularly Argentina, and addresses what makes Brazil different. It illustrates the persistence of diverging views on the military past in Brazil and suggests that, in contrast to Argentina, it is not yet possible to speak of a 'dominant memory' but rather of an 'unmastered past'.

\section{The Transition to Democracy and its Legacy}

In order to analyse the specificities of the Brazilian culture of memory, it is useful to consider the wider historical context and briefly address the transition process to democracy. Two key characteristics of the military regime in Brazil (1964-1985) influenced the subsequent memory culture: its attempt to appear democratic while governing by dictatorial means (Smith, 1997: 187; Aquino, 2000: 275), and its long period of rule, which ended with a gradual and 'peaceful' transition. Unlike in Argentina or Chile, democratic institutions and procedures were maintained but in a distorted manner: elections were still held, but manipulated; Congress remained intact, but was threatened and closed when it disobeyed the regime's orders. The military regime in Brazil was ruled by military presidents on a rotational basis, rather than strong dictators. The fourth military President Ernesto Geisel (1974-1979), initiated a political opening of the regime, the so-called distensão, which led to a reduction in human rights violations. This new strategy was demanded 'from below' as the popularity of the regime declined in the 1970s (Jornal do Brasil, 1977; Lamounier, 1980: 7; Alves, 1985). Compared to Argentina and Chile, the number of dead and disappeared in Brazil was much lower: officially calculations place the figure at 474, whereas in Argentina estimates are in the region of 10,000-30,000 and in Chile between 3,000 and 10,000 
assassinations (Aquino, 2000: 271; SEDH, 2007: 32-33). Therefore, the number of families directly affected by human rights violations was accordingly smaller in Brazil, which arguably made a reworking of the military past less of an immediate concern. Moreover, the gradual transition in Brazil contrasts with the collapse of the military regime in Argentina, where the armed forces were discredited by their military defeat in the 1982 Falklands/Malvinas War (Hagopian, 1993: 468). Like most other military regimes in Latin America, the Argentinean regime imploded amid financial disaster, whereas Brazil's regime achieved spectacular economic growth during the so-called economic miracle (1968-1973) (Hagopian, 1993: 468). While the annual economic growth rates achieved in Brazil were undeniably historic, scholars have criticised the miracle myth for concealing the fact that the one-sided growth deepened social divisions and augmented the national debt. Hence, the legacy of the armed forces in Brazil was more ambivalent than in Argentina.

Debates about the Amnesty Law have played a key role in the memory discourse about the military past in Brazil. The amnesty movement, which gained impetus from 1975 onwards, was one of the first movements to break the silence surrounding memory. It enjoyed widespread public support and contributed to the 1979 Amnesty Law, which was partly a response to the demands of the opposition (Alves, 1985: 211). The Amnesty Law was a compromise and the result of prolonged negotiations as the Geisel government faced pressure from the opposition party, the Movimento Democrático Brasileiro (Brazilian Democratic Movement; MDB) and military hardliners alike (Alves, 1985: 211). Carlos Fico (2009) highlights the delicate political situation during which the amnesty was negotiated, as the policies initially followed by President Geisel were attacked by hardliners, or linha dura, a more radical camp of the regime who favoured the military remaining in power. While Geisel's followers intended to utilise the Amnesty Law to weaken the MDB, the only opposition party allowed during the regime since the installation of a two-party system in 1965, the amnesty movement itself was split: one camp demanded the punishment of military human rights violators, the other, including the majority of the MDB, acknowledged a gèneral amnesty as a compromise (Fico, 2009: 4-5). At that time, the strategy of the opposition was one of conciliation and they accepted the general Amnesty Law even if it meant granting total impunity to military officials involved in the repressive organs (Skidmore, 1991: 426; Fico, 2009: 1, 13). Although the 1979 Amnesty Law was issued by the military regime, no post1985 civilian government has annulled it since. In contrast, the Argentineans revoked their Amnesty Law in 1983, resulting in several military generals being sentenced and imprisoned throughout the 1980s, including the former dictator Jorge Rafael Videla (Catela, 2000: 301-315). Among Latin American countries, Argentina has been the one to punish those responsible for state violence most rigorously, while others have been characterised by partial impunity. In Bolivia a law protected the violent dictator Hugo Bánzer from being prosecuted. In Uruguay, the public took to the streets when the government tried to abandon the amnesty issue, but when the citizens were asked to decide whether to revoke the Amnesty Law, 57 per cent of the population (out of an 84.78 per cent electorate) supported it, thus rejecting trials, while only 43.34 per cent demanded its alteration (Catela, 2000: 301-315; Ferreira Bastos, 2009: 399-400). In Chile, 129 former officials from the political police, Dirección de Inteligencia Nacional (DINA; National Intelligence Directorate), are currently being tried (BBC News, 2009).

Recent debates about the Amnesty Law have prompted new public disputes about the military past. Two incidents played a significant role: a court case against a former military official accused of torture; and a Supreme Court appeal by the OAB, issued 
in October 2008, to revoke the 1979 Amnesty Law. The first trial in the history of Brazil against a military official responsible for torture during the military regime was the court case of the Almeida Teles family against Colonel Carlos Alberto Brilhante Ustra, leader of the São Paulo branch of the notorious repressive organ, the Centro de Defesa Interna - Departamento de Ordem Interna (CODI-DOI; Centre for Internal Defence-Department of Internal Order) between 1970 and 1974, also referred to as Doi-Codi (Santos, Teles and Teles, 2009: 545). In September 2006, a judge in São Paulo accepted the charges brought by the Almeida Teles family against Ustra arguing that the statute of limitations did not apply to violations of human rights (Teles, 2009: 1). Paradoxically, the court could not pass a criminal judgement, because the Amnesty Law protected Ustra from judicial punishment. Therefore, in October 2008, the court condemned Ustra 'morally and politically' by declaring him responsible for torture (Albuquerque, 2008). In other words, the Ustra case was a symbolic trial against a convicted torturer who, according to the 1979 Amnesty Law, enjoyed general amnesty and therefore could not be punished.

Partly due to the Ustra case, the Amnesty Law has been increasingly questioned. One key figure to challenge it has been the lawyer Hélio Bicudo, who has pointed out that torture is a common crime and thus not covered by the Amnesty Law, which explicitly refers to 'political' crimes (Albuquerque, 2008). In 2008, the OAB used this argument to appeal to the Supremo Tribunal Federal (STF; Brazilian Supreme Court) asking for torture to be exempted from the Amnesty Law. On 28 April 2010, the Brazilian Supreme Court took a historic decision when it refused to revoke the Amnesty Law by seven votes to two (Folha Online, 2010b). Most STF ministers justified their vote with recourse to the historical context, asserting that the $\mathrm{OAB}$ accepted the law at the time it was introduced, and that the amnesty was 'bilateral' and thus to the benefit of the opposition and state officials alike (Folha Online, 2010b, 2010c). The OAB, Vannuchi, former Justice Minister Tarso Genro, along with various human rights organisations, including Amnesty International and the group Tortura Nunca Mais (Torture Never More), condemned this decision. While OAB President Ophir Cavalcante argued that the STF 'was not timely' ('perdeu o bonde da história') (Folha Online, 2010c), Vannuchi and the Vice-President of Torture Never More, Marcelo Zelic, called it 'regrettable' (Bocchini, 2010). The debate about the Amnesty Law remains controversial, as the Inter-American Court of Human Rights (IACHR) of the Organisation of American States (OAS) is currently examining whether the Brazilian Amnesty Law violates international human rights law (Folha Online, 2010d).

The upholding of the Amnesty Law does not necessarily equate to denying the military past. Supreme Court Minister Eros Grau, who was himself tortured during the regime, voted against the revocation but warned that the practice of torture should not be forgotten (Folha Online, 2010b). Several further victims oppose punishment of military human rights violators, including ex-President Fernando Henrique Cardoso, who was also granted amnesty, Senator Arthur Virgílio, whose father lost his political rights during the regime, and the former guerrilla fighter and historian, Daniel Aarão Reis (Conde, 2010; Globo Online, 2010). Aarão Reis, an expert on the history of the military regime, argues that officials responsible for repression have already been morally condemned by the Brazilian people (Aarão Reis, 2004: 40-41; Conde, 2010). Thus, the debate about the Amnesty Law is controversial and complex. Although judicial prosecutions are an effective catalyst and highly symbolic, they are not the only form of public remembrance of the authoritarian past. Collective memory can manifest in public demonstrations, debates and speeches, educational programmes, 
museums and varying forms of Truth Commissions. Many post-authoritarian countries opted for Truth Commissions that operated without judicial prosecutions such as the Truth and Reconciliation Commission in South Africa (1996-1998). The planned Brazilian Truth Commission will not have the right to punish either, but to investigate human rights violations and write a report that incorporates recommendations (Folha Online, 2010a).

\section{The State's 'Politics of Silence'}

Although other forms of collective memory than judicial punishment exist, until recently neither the state nor large sectors of the Brazilian population utilised them. After the amnesty movement (1975-1979) and the so-called Diretas-Já movement (1983-1984), which demanded direct presidential elections in 1985, wider public support for reworking the military past vanished. This public inertia differs crucially with Argentina where victims' families and human rights organisations took to the streets in the late 1970s and early 1980s, demanding the acknowledgement and punishment of human rights violations embodied in the slogan 'memory, truth and justice' (Catela, 2008: 184). Eventually, politicians actively addressed this question and the protection of human rights was elevated to become the foundation of the new democracy (Jelin, 2008: 347). A significant step was the revocation of the Amnesty Law by Raúl Alfonsín, president from 1983 to 1989 (Jelin, 2008: 345-347). However, Alfonsín subsequently slowed down the judicial process by passing the Full Stop Law (1986) and the Law of Due Obedience (1987). He argued that he wanted to avoid a national schism. These laws were revoked in 2003 by President Kirchner opening the way for further prosecutions. In Brazil, by contrast, victim support groups and human rights organisations still struggle to capture widespread public sympathy. At the Lasa Conference 2009, the US scholar Ann R. Schneider reported that the group Torture Never More unsuccessfully tried to erect a statue in memory of the torture victims in Rio at Flamengo beach. The world-famous architect, Oscar Niemeyer, had designed a sculpture showing a huge Niemeyeresque bow from which a person was hanging, but the project failed because it did not receive support from the municipal government, and, more importantly, could not raise enough money in the limited time-span granted. Yet, in Glória, one can observe a large bust of the Brazilian dictator, Gétulio Vargas. Prior to the government's new strategy, the only statue thematising torture was in Recife, portraying the so-called 'parrot's perch' inaugurated in 1993.

For decades the primary actors in the campaign to remember the military past have been the group Torture Never More, the Comissão de Familiares de Mortos e Desaparecidos Políticos de São Paulo (Commission of the Families of the Killed [or Dead] and Disappeared Political Activists of São Paulo), and the Comitê Catarinense Pró-Memória dos Mortos e Desaparecidos Políticos de Santa Catarina (Committee for the Memory of the Political Dead and Disappeared of Santa Catarina) (Coimbra, 2001: 11-19). These groups exerted prolonged pressure on the state to take steps towards tackling the military legacy (Santos, Teles and Teles, 2009: 472-495). The first systematic report on torture, the project Brasil Nunca Mais, was not initiated by the state, but the archdiocese of São Paulo (Arquidiocese de São Paulo, 1985). In the 1990s, several archives of the Departamento de Ordem Política e Social, Dops (Department of Political and Social Order) and the Departamento Estadual de Ordem Política e Social (DEOPS; State Department of Political and Social Order) were opened in response to demands from the families of the disappeared (Catela, 2009: 444-471). In 1995, 
members of various victim associations presented a list of demands that included the state publicly assuming the responsibility for murder and torture (SEDH, 2007: 32-33). The state responded with the creation of an investigation commission and compensation payments ranging from approximately US\$99,500 to US\$150,000. Yet again, however, the burden of proof lay with the victims' families, not the state, otherwise they were not entitled to receive compensation (SEDH, 2007: 33-34, 36). Families furthermore demanded that the state must explain the circumstances under which guerrilla fighters in Araguaia were murdered, and take responsibility for finding their dead bodies. The Araguaia guerrillas constitute the biggest group of victims during the regime, with a total of 64 cases of murder, of which most of the dead bodies are still missing. According to the official report of the SEDH and human rights activists, for a lengthy period the state sabotaged the investigation of these cases (SEDH, 2007: 38, 43; Santos, Teles and Teles, 2009: 376, 473-474, 489, 491).

Statesmen also repressed memory by blocking access to archive material. I use the term 'state' as an equivalent to government excluding the armed forces, which technically belong to the state. For the first time in the history of Brazil, the Constitution of 1988 adopted a Freedom of Information Act giving citizens the right to access data held by public bodies (Costa, 2008: 21). In 1991, the so-called Archive Law ordered that public documents must be preserved for subsequent public viewing, and established that further decrees would regulate the terms for access (Costa, 2008: 20). A 1997 decree elaborated criteria for classifying the documents and delegated responsibility for control over access conditions to a committee. However in 2002, President Fernando Henrique Cardoso reversed the process of liberalisation only three days before leaving office, issuing a decree that drastically prolonged the closure of government files to the public. This decree undermined the recommendations of the Conselho Nacional de Arquivos, Conarq (National Archive Council) by permitting the files to remain closed for 100 years (Fico, 2004: 126; Costa, 2008: 23-24). Although it violated the 1991 Archive Law, which had ruled that the closure period should be determined by a special commission rather than the government, the Brazilian Congress ratified this law in 2005. Other than material from the former political police, which some regional governments opened for consultation in the 1990s (Catela, 2009: 451-455), the only documents made accessible by the Federal Government were the archives of the former national intelligence service, Serviço Nacional de Informação (SNI), opened to the public in December 2005. In short, the overall strategy of post-1985 governments has been to silence the military past. The only active steps taken were to officially apologise for the state violence in 1995, to create a special commission to investigate these cases, and to pay compensation to the victims' families (Catela, 2000: 299-300).

One explanation for the state's inertia is that, unlike in Argentina, the governments did not exert enough pressure on the armed forces, which remained a powerful institution in post-1985 Brazil. The extent of the power retained by the armed forces after redemocratisation is a contentious issue among scholars. While Jorge Zaverucha (1994) speaks of a 'tutelary democracy' and contends that several mechanisms to reinforce military power survived the transition, Wendy Hunter (1997) and Celso Castro (2000: 18-30) emphasise significant changes, including the creation of the Ministry of Defence, which placed the military under civilian rather than military leadership. Although less powerful today than under military rule, in December 2009 the armed forces were still sufficiently influential to force President Lula to water down the proposal for the Truth Commission. While in Brazil the armed forces retained considerable control over the government, Argentinean governments have publicly 
criticised their military for sustaining political support (Catela, 2008: 183). Whereas the Argentinean population mobilised to advance the human rights agenda and exert pressure on the state, in Brazil public inertia and differences of opinion enabled the state to silence the authoritarian past.

\section{'Dominant Memory' or Silence and Consent?}

Although the term 'dominant memory' seems appropriate for the Argentinean context, public memory in Brazil is better described as being 'in denial' or as deeply divided. Methodologically, it is difficult to grasp the precise meaning of 'dominant memory'. To define it loosely, a 'dominant memory' occurs when the majority of a given group or nation agrees upon narrating a part of history in a broadly accepted manner. The notion of 'collective memory' is similarly challenging to pinpoint. Scholars readily quote Maurice Halbwachs, although, as Peter Burke (2004: 58) observed, it is unclear when it is justifiable to generalise from personal memory to a collective or national memory. Kerwin Lee Klein (2000: 130-136, 140) contests that 'collective memory' represents memory as yet another 'structural' category, and Burke (2004: 55) reminds us that as many memories exist as social identities. Rather than conceiving of 'dominant memory' as a fixed category, I adopt Antonio Gramsci's (1971: 181-182) historically specific understanding of society as being in a permanent state of struggle over 'social, political and cultural leadership'. Similar to his concept of 'hegemony', I suggest understanding 'dominant memory' as the moment when an ideology or belief 'tends to prevail'.

Ludmila da Silva Catela (2008: 182-186) argues that, in Argentina, families of victims and human rights organisations progressively created a 'dominant memory', characterised by claims for 'human rights' and 'justice', thus shining the spotlight on the victims' memory. She criticises this 'dominant memory' for omitting the political goals of the disappeared and denying their political struggles prior to the coup. It also overlooks the use of violence by opposition groups, and therefore redefines the meaning of 'human rights', linking it exclusively to a 'privileged' group of victims. As Catela (2008: 186) has convincingly argued, human rights have become 'emblematic'. In Argentina, this 'dominant memory' has manifested in human rights commissions, museums, exhibitions, school and university programmes, place names, and memorials. In the Brazilian case, I propose that the term 'dominant memory' is less appropriate. Gavriel D. Rosenfeld (2009: 126-127) has suggested another concept, the 'unmastered past', that describes a historical legacy that is unsettled in collective memory, for example, when victims and perpetrators cannot overcome their conflicts. In contrast to Argentina, the key feature of Brazilian collective memory has been silence and polarisation, as public consensus is lacking, and a significant number of Brazilians view the military era in a positive way. Public consensus has not yet materialised in decisive forms such as opinion polls in which a clear majority condemns the regime, less contested interpretations of the regime, or museums, statues and educational activities, not only unanimously patronised by the state but also endorsed by the public. While the concept of 'unmastered past' is, I suggest, more suitable for post-1985 Brazil, the notion of 'dominant memory' better fits the Argentinean case.

Survey responses confirm that public opinion on military rule is highly fragmented. On 27 March 1994, the Folha de S. Paulo published a Datafolha survey based on 6720 interviewees showing that 70 per cent regarded the economic situation of Brazil in 1994 as worse than during the military regime, while 55 per cent believed that the political 
situation had deteriorated in 1994 compared to under military rule (Souza, 2009). Most respondents (51 per cent) believed responsibility for this crisis lay with the post-1985 governments whereas only 15 per cent blamed the military regime. While the validity of these surveys has been questioned, a qualitative oral history sample I collected in 2007 in Rio confirms these results and illustrates that public opinion on the military regime is profoundly divided. My samples were distinguished by class, gender and age and consisted of a total of eleven interviews (with Souza, Cleofas, Corrêa, Ferreira, Caitano, Pinto, João, Dalva, Tereza, anonymous and Santos in 2007). Since my interview sample was small, the interviewees picked randomly and the survey deliberately qualitative, the responses cannot be regarded as representative of the Brazilian population. Nonetheless, the varying views that crossed the boundaries of gender, age and class confirm that Brazilian society is deeply divided. Using the narrative method, I found critical and sympathetic voices among all groups. Some interviewees also had ambivalent views or gave contradictory responses: only two interviewees portrayed the military years as totally negative, while three declared the era extremely positive and two fairly positive, and the rest had mixed opinions or contradicted themselves. Many interviewees, including the majority of slum dwellers, told a narrative of the 'golden past' indicating that their responses were informed by current problems, including unemployment and drug-related violence. Several interviewees praised economic progress and modernisation under the regime, while not denying that harsh repression also occurred. In sum, whilst the responses of this small sample are not representative, the diverse views that cut across gender, age and class confirm that Brazilian society is deeply divided and raise doubts about whether a 'dominant memory' exists.

While I suggest that public memory is now characterised by silence and strongly divergent views, some authors believe it is possible to speak of a 'dominant memory' in post-authoritarian Brazil. For example, in 1994, Gláucio Soares and Maria Celina d'Araújo edited a book on the legacy of the coup in which they point out that the post1964 violence is commonly attributed exclusively to the armed forces. They illustrate this with reference to the samba school Império Serrano, which mocked the military institution during the 1986 carnival (Soares and d'Araújo, 1994: 1, 3). Ten years later, Daniel Aarão Reis co-edited a similar commemorative volume reflecting on the military overthrow and its memory. Aarão Reis (2004: 40-41) focuses on the 'dominant memory' in which the 'gorillas' lost popularity and legitimacy to the 'left-wing camp' as: '[Defeated] in the field of social and historical confrontations the left could re-emerge as winner in the struggles over memory.' According to his critique, the memory of the 'revolutionary reformist project' - the attempt to establish a socialist or communist society - vanished, as the left was 'victimised', while the armed forces were 'stigmatised' (Aarão Reis, 2004: 50). Within ten years, the common perception of the regime had changed from one that held the armed forces exclusively responsible for the violence, to one which came to embrace the 'left' as its victim.

Interestingly, not only renowned historians but also a significant number of military officers attest to a 'dominant memory', including ex-Minister Jarbas Passarinho. Former supporters of the regime frequently criticise this 'hegemonic memory', intended to 'defend' or 'restore' military honour (Passarinho, 1995). To illustrate this, in 2003 the armed forces published a fifteen-volume edition of oral history interviews related to the military regime. In their introduction (Biblioteca do Exército, 2003, Vol. I: 9-10) the editors accuse the media, historians and teachers of 'falsifying' history and openly practicing 'vindictiveness' - revanchismo. Revanchismo is a politically biased term commonly used by military officials to refute punishment or criticism of violent actions, 
including torture, which occurred during the regime. The term suggests that certain courses of actions, such as the demand to prosecute torturers, are pursued for personal vengeance, when in fact they belong to a public and political, and not a private, sphere (Greco, 2009: 532-533). The editors condemn the fact that the armed forces are being victimised while the 'criminals' benefit from compensations (Biblioteca do Exército, 2003, Vol. I: 10). Overall, some scholars and military representatives alike argue that a 'dominant memory' of the military regime in Brazil exists, while I propose that, in comparison to Argentina, the memory culture is best characterised by the concept of 'unmastered past'. However, it is likely that a dominant memory will develop in the forthcoming years now that the state has changed its 'politics of memory'.

\section{The State's New Policy: Fostering the Memory of Left-wing Opposition Groups}

During the last five years, I argue, the memory of the military regime in Brazil has started to alter, as the state has adopted a new policy. The Federal Government now actively champions the remembrance of the authoritarian past and attempts to mobilise a public memory culture. As a first step, Human Rights Minister Vannuchi launched two major projects: Direito à memória e à verdade (The Right of Memory and Truth, 2006) (SEDH, 2007) and Memórias Reveladas (Revealed Memories, 2009) (Memórias Reveladas, 2009). This recent course of action has materialised in educational programmes, monuments, museum spaces and official reports on human rights violations, all focusing on victims of torture and death. These latest 'politics of memory' have climaxed in the current debate on the Truth Commission.

Vannuchi's first project, 'The Right of Memory', comprised four key initiatives: the publication of a final report of the Special Commission of Killed and Disappeared for Political Reasons; the inauguration of three monuments in São Paulo and Rio honouring students and workers killed during the regime; and the touring exhibition, 'The Dictatorship in Brazil 1964-1985' (SEDH, 2007). Furthermore, this memory project enabled 3,000 teachers to participate in a four-month distance-learning course on human rights and the military 'dictatorship', which integrated readings, tutorials, videos and chat forums. In particular, São Paulo has witnessed various memory projects in 2008 and 2009. On 22 September 2009, Vannuchi inaugurated the Memorial da Resistência (Resistance Memorial) (Agência Brasil, 2009), a monument originally unveiled by the Public State Archive of São Paulo in 2002 as the Liberty Memorial. In 2007 , it was transformed into a museum with the purpose of preserving the 'memory of resistance and repression' through education and culture. The stated goal of the project is to 'sensitise and promote the importance of practising democracy, citizenship and human rights' (Pinacoteca, 2009). It also introduces the structure of the DEOPS and reconstructs everyday life in the prison cells during the military regime. It is interesting that the organisers renamed the memorial to incorporate the term 'resistance', a term that is also employed in the official report of the SEDH (2007). This use of language has produced lively debate among scholars, including Daniel Aarão Reis, a critic of the memory discourse of the armed struggle. Former guerrilla fighter Aarão Reis (2004: 29-52) has asserted that the opposition groups never fought for democracy, and that the term 'resistance' is inappropriate. Marcelo Ridenti (2004: 57), in contrast, has argued that the word 'resistance' can be readily applied to certain groups who used this term in their documents and who had defensive rather than offensive goals. 
Paula Nascimento D'Araújo (2006: 93-104) also distinguishes between two different student movements: the 1968 generation with revolutionary ambitions and the 1970s generation with a democratic mission. Altogether, while Aarão Reis rightly emphasises that the generation involved in the armed struggle wanted a 'social revolution', the second student movement in the 1970s demanded the restoration of democracy. The new memory discourse clearly silences this debate.

The stated aim of the second major government initiative, Memórias Reveladas, is to create a research centre on 'political struggles during the 1960s and 1980s' (Memórias Reveladas, 2009b). Memórias Reveladas is designed to stimulate research, provide access to sources, and contribute to the academic and political debate. A network of archives is being established to enable researchers to download documents. Further initiatives include expositions, books, educational material, seminars and awards for monographs on the military regime, the first to be announced in November 2010. The Memórias Reveladas campaign has been widely broadcast in the media accompanied by the slogan 'So that we do not forget. So that it never happens again' (Para que não se esqueça. Para que nunca mais aconteça) (Veja, 2009).

The question arises of why state interference should occur at this particular point. Besides the fact that more time has passed, demands from international human rights organisations certainly provide another explanation. The second sentence of the Special Commission's report points to the UN, and declares more information on human rights violations to be 'imperative' given Brazil's 'new status on the international scene' (SEDH, 2007). The President of the OAB, Cezar Britto, recently defended the Truth Commission, pointing out the paradox that Brazil was protecting democracy in Haiti, but was afraid to deal with its own past (Lima, 2009). International demands on the Brazilian government, prosecution in Latin American neighbour states and the general global support for human rights are indisputably pushing the Brazilian government towards taking action. In November 2009, the UN High Commissioner for Human Rights, Navanethem Pillay, claimed that torture could not go unpunished, and that the lack of debate about torture was, in fact, likely to strengthen the current practice of torture. She demanded that the Brazilian government establish a clear political programme to combat impunity (Laboissière, 2009). Another international institution pressuring Brazil - alluded to earlier - is the IACHR, which disapproves of amnesty laws issued under non-democratic regimes (Santos, Teles and Teles, 2009: 380-381, 447-495). Vannuchi and his followers have frequently drawn attention to international demands to bolster their claims.

The origins of the new 'politics of memory' in Brazil are partially rooted in the agents advancing this agenda. As union leader, Lula himself played a key role in opposing the military regime and in the process of democratisation (Alves, 1985: 203, 209). Various members of Lula's government were guerrilla fighters or student leaders who opposed the regime. According to Maria Celina D’Araújo (2010), 49 per cent of the ministers in Lula's two governments have 'political experience in the underground' such as clandestine opposition to the dictatorship. Vannuchi and Presidential Chief of Staff Dilma Rousseff both experienced prison and torture. In Vannuchi's case, he was imprisoned in 1971 at the age of twenty-one and only discharged in 1976 (Franco, 2010). The proposal comes at the end of Lula's second term when the president's power and prestige are substantiated by Brazil's economic growth and his record-breaking approval ratings place him ahead of all presidents after democratisation (Folha Online, 2008; Guerreiro, 2009). In December 2009, approval for his government rose to 72.5 per cent while his personal support amounted to 84 per cent in January 2009 (Guerreiro, 
2009), making it seem likely that Lula felt strong enough to deal with the military past. The news agency Agência Brasil reports that Lula repeatedly told Vannuchi he did not want to be remembered by history as someone who suppressed the military past (Pimentel, 2008). If Dilma Roussef loses the 2010 presidential election, Lula will have ensured that he pushed forward that agenda while still in office.

Conceiving of the collective memory of the military past as a struggle, I briefly want to illustrate that frictions have now advanced beyond the government. In the run-up to the 2010 elections, parts of the media and the political right attacked the proposal for the Truth Commission to discredit Lula's party. On 13 January 2010, the magazine Veja (2010: 64) published an article entitled 'Coisa de maluco' ('Matter of a madman') accompanied by a picture of Minister Vannuchi with the subtitle 'Not Human: The Federal Minister Paulo Vannuchi, ex-militant of a terrorist group and drafter of that decree: if it does not work with a revolver, he does it with a pen' ('Deshumano. O secretário Paulo Vannuchi. Ex-militante de organização terrorista e artífice do decreto: se não foi com o revólver, vai com caneta'). Using the emotive term 'ex-terrorist' instead of his title, Federal Minister, the article accuses Vannuchi of 'revanchism' and dismisses the entire Lula government as 'crazy' ('petista doido') and 'bolchevique'. Veja even claims that Vannuchi uses human rights as a 'pretext' to fulfil his political agenda, a claim supported by the conservative daily, O Estado de São Paulo (Mendes, 2010), which reports that the government 'uses the United Nations as a shield for its National Programme of Human Rights'. Marcos Rolim (2010), a member of the PNDH-3 commission, criticises the media for spreading inaccurate information and points out that the commission opted for the milder version of a 'Truth Commission' instead of a 'Justice and Truth Commission' that would include prosecutions. Rolim also demonstrates that many of the points objected to had already been accepted as part of the national human rights plans issued under ex-President Fernando Henrique Cardoso.

\section{Conclusion}

During the last five years, I have argued, the Brazilian state has developed a new strategy: to actively foster and mobilise a memory culture honouring the struggles of left-wing opposition groups for 'democracy' and denouncing human rights abuses committed during the military regime. While Human Rights Minister Vannuchi launched a series of memory programmes without major opposition, struggles have recently culminated in a crisis extending beyond the government. A historic proposal for a National Truth Commission in December 2009 prompted protests from Defence Minister Jobim and the armed forces who blackmailed Lula to modify the project. More than just a reflection of the 'unmastered past', this clash demonstrates that the 'politics of memory' have been hijacked by a contemporary power struggle. Nonetheless, the proposal also illustrates the transformation of the official 'politics of memory': whereas for decades the Brazilian state was passive towards human rights claims, or even sabotaged them, today not only Vannuchi but also ex-Minister of Justice Tarso Genro and the OAB are enthusiastically promoting the human rights agenda.

Considering that previously the most significant actors breaking the silence were families of victims, human rights organisations, lawyers, academics and the Catholic Church, Brazil has come a long way. A Truth Commission would represent a landmark in the struggle for a public memory culture of the military regime. Now that the Supreme Court has refused to revoke the 1979 Amnesty Law, Brazil needs to advance 
other forms of collective memory. However, given the ferocity of theattacks Vannuchi is facing, I fear that the Truth Commission's measures to rework the military past will fall short of introducing major changes and will once again be gradual-a compromise.

\section{Acknowledgements}

The author wishes to thank M. Röhrig Assunção for his valuable comments. She furthermore wishes to thank L. McKee and her interviewees. Support for this research was provided by the Arts and Humanities Research Council and the University of Essex, UK.

\section{References}

Aarão Reis, D. (2004) 'Ditadura e sociedade: as reconstruções da memória' in D. Aarão Reis, M. Ridenti, and R. P. Sá Motta (eds.) O golpe e a ditadura militar: 40 anos depois (1964-2004). EDUSC: Bauru, 29-52.

Agência Brasil (2009) Vannuchi inaugura memorial em homenagem a estudantes mortos durante a ditadura. [WWW document]. URL http://www.agenciabrasil.gov.br/noticias/ 2009/09/22/materia.2009-09-22.4546596183/view [accessed 25 October 2009].

Agência Brasil (2010) Governo deve alterar proposta de comissão da verdade sobre episódios da ditadura militar. [WWW document]. URL http://www.agenciabrasil.gov.br/noticias/ 2009/12/30/materia.2009-12-30.1811332565/view [accessed 6 January 2010].

Albuquerque, F. (2008) Familia comemora condenação moral e política de coronel torturador. [WWW document]. URL http://www.agenciabrasil.gov.br/noticias/2008/10/10/ materia.2008-10-10.7483232573/view [accessed 17 November 2009].

Alves, M. H. M. (1985) State and Opposition in Military Brazil. University of Texas Press: Austin.

Aquino, M. A. (2000) 'A especifidade do regime militar brasileiro: abordagem teórica e exercício empírico' in D. Aarão Reis (ed.) Intelectuais, história e política: séculos xix e $x x$. Viveiros de Castro: Rio de Janeiro, 271-289.

Aquino, Y. (2009) Tarso nega crise entre o ministério da defesa e a secretaria especial de direitos humanos. [WWW document]. URL http://www.agenciabrasil.gov.br/noticias/2009/ 12/30/materia.2009-12-30.6475043220/view [accessed 1 January 2010].

Arquidiocese de São Paulo (1985) Um relato para a história. Brasil: nunca mais. Vozes: Petrópolis.

Biblioteca da Exército (2003) 1964-31 de março: o movimento revolucionário e a sua história. Vol. 1-15. Biblioteca do Exército: Rio de Janeiro.

Bocchini, B. (2010) Manifestação pede condenação de torturadores. [WWW document]. URL http://agenciabrasil.ebc.com.br/home/-/journal_content/56/19523/954846 [accessed 10 June 2010].

BBC News (2009) Arrests in Chile for Rights Abuse. [WWW document]. URL http://news.bbc. co.uk/2/hi/americas/8234982.stm [accessed 2 September 2009].

Burke, P. (2004) Varieties of Cultural History. Polity Press: Cambridge.

Castro, C. (2000) The Military and Politics in Brazil: 1964-2000. [WWW document]. URL http://www.brazil.ox.ac.uk/workingpapers/celso10.pdf [accessed 29 May 2006].

Catela, L. D. S. (2000) 'Em nome da pacificação nacional: anistias, pontos finais e indultos no cone sul' in M. C. D'Araújo, and C. Castro (eds.) Democracia e forças armadas no cone sul. Editora Fundação Getúlio Vargas: Rio de Janeiro, 293-328.

Catela, L. D. S. (2008) 'Violencia política y dictadura en Argentina: de memorias dominantes, subterráneas y denegadas' in C. Fico, M. de Morães Ferreira, M. P. Araújo, and 
S. V. Quadrat (eds.) Ditadura e democracia na América Latina: balanço histórico e perspectivas. Editora Fundação Getúlio Vargas: Rio de Janeiro, 179-200.

Catela, L. D. S. (2009) 'Do segredo à verdade ... processos sociais e políticos na abertura dos arquivos da repressão no Brasil e na Argentina' in C. M. Santos, E. Teles, and J. A. Teles (eds.) Desarquivando a ditadura: memória e justiça no Brasil. Vol. II. Aderaldo and Rothschild Editores: São Paulo, 444-471.

Coimbra, C. M. B. (2001) 'Tortura ontém e hoje: resgatando uma certa história'. Psicologia em Estudo 6(2): 11-19.

Conde, M. (2010) Historiadores discutem revogação da lei de anistia. [WWW document]. URL http://oglobo.globo.com/blogs/prosa/posts/2010/01/09/historiadores-discutemrevogacao-da-lei-de-anistia-255996.asp [accessed 12 January 2010].

Costa, C. M. L. (2008) 'O direito à informação nos arquivos brasileiros' in C. Fico, M. de Moraes Ferreira, M. P. Nascimento Araujo, and S. Viz Quadrat (eds.) Ditadura e democracia: balanço e perspectivas. Editora Fundação Getúlio Vargas: Rio de Janeiro, $17-26$.

D’Araújo, M. C. (2010) Os ministros da nova república: notas para entender a democratização do poder executivo. [WWW document]. URL http://cpdoc.fgv.br/artigos [accessed 10 January 2010].

D’Araújo, M. P. (2006) 'Estratégias de resistência e memória da luta contra o regime militar no Brasil (1964-1985)' in J. R. Martins Filho (ed.) O golpe de 1964 e o regime militar: novas perspectivas. Edufscar: São Carlos, 93-104.

Éboli, E. (2009) 'Decreto abre crise entre ministros'. O Globo, 30 December, 4.

Ferreira Bastos, L. E. A. (2009) 'A anistia brasileira em comparação com as da américa latina: uma análise na perspective do direito internacional' in C. M. Santos, E. Teles, and J. A. Teles (eds.) Desarquivando a ditadura: memória e justiça no Brasil. Vol. II. Aderaldo and Rothschild Editores: São Paulo, 386-405.

Fico, C. (2004) Além do golpe: versões e controvérsias sobre 1964 e a ditadura militar. Record: Rio de Janeiro, São Paulo.

Fico, C. (2009) A negociação parlamentar da anistia de 1979 e o chamado 'perdão aos torturadores. [WWW document]. URL http://www.ppghis.ifcs.ufrj.br/media/Torturadores.pdf [accessed 10 September 2009].

Folha Online (2008) Aprovação de Lula bate recorde bistórico, diz Datafolha. [WWW document]. URL http://www1.folha.uol.com.br/folha/brasil/ult96u444114.shtml [accessed 10 October 2009].

Folha Online (2010a) Câmara começará a analisar comissão da verdade. [WWW document]. URL http://www1.folha.uol.com.br/poder/740957-camara-comecara-a-analisarcomissao-da-verdade.shtml [accessed 9 June 2010].

Folha Online (2010b) Por 7 a 2, STF rejeita revisar lei da anistia para punir torturadores. [WWW document]. URL http://www1.folha.uol.com.br/folha/brasil/ult96u728076. shtml [accessed 14 June 2010].

Folha Online (2010c) OAB diz que STF 'perdeu o bonde da história'. [WWW document]. URL http://www1.folha.uol.com.br/folha/brasil/ult96u727968.shtml [accessed 14 June 2010].

Folha Online (2010d) Lei da Anistia é debatida em julgamento do Brasil na Corte da OEA. [WWW document]. URL http://www1.folha.uol.com.br/folha/brasil/ult96u738985. shtml [accessed 14 June 2010].

Franco, B. M. (2010) Cruzada de Vannuchi contra a prática de tortura começou na prisão durante o regime militar. [WWW document]. URL http://oglobo.globo.com/pais/mat/ 2010/01/12/cruzada-de-vannuchi-contra-pratica-de-tortura-comecou-na-prisaodurante-regime-militar-915515660.asp [accessed 14 June 2010].

Globo Online (2010) Comissão da verdade é a favour das forças armadas, diz Vannuchi. [WWW document]. URL http://g1.globo.com/Noticias/Politica/0,,MUL15617785601,00.html [accessed 20 April 2010].

Gramsci, A. (1971) Selections from the Prison Notebooks. Lawrence and Wishart: London. 
Greco, H. A. (2009) 'Anistia anamnese vs. anistia amnésia: a dimensão trágica da luta pela anistia' in C. M. Santos, E. Teles, and J. A. Teles (eds.) Desarquivando a ditadura: memória e justiça no Brasil, Vol. II. Aderaldo and Rothschild Editores: São Paulo, $524-540$.

Guerreiro, G. (2009) Aprovação de Lula bate recorde histórico, diz Datafolha. [WWW document]. URL http://www1.folha.uol.com.br/folha/brasil/ult96u498149.shtml [accessed 10 October 2009].

Hagopian, F. (1993) 'Review: After Regime Change: Authoritarian Legacies, Political Representation, and the Democratic Future of South America'. World Politics 45(3): 464-500.

Hunter, W. (1997) Eroding Military Influence in Brazil-Politicians against Soldiers. University of North Carolina Press: Chapel Hill.

Jelin, E. (2008) 'La justicia después del juicio: legados y desafios em la Argentina postdictatorial' in C. Castro, and M. C. D'Araújo (eds.) Militares e política na nova república. Editora Fundação Getúlio Vargas: Rio de Janeiro, 341-360.

Jornal do Brasil (1977) Gallup culpa reformas pela queda de prestígio de Geisel. Jornal do Brasil, 26 May.

Klein, K. L. (2000) 'On the Emergence of Memory in Historical Discourse'. Representations 69:127-150.

Laboissière, P. (2009) Alta-comissária da ONU critica falta de ações contra abusos cometidos na ditadura militar. [WWW document]. URL http://www.agenciabrasil.gov.br/noticias/ 2009/11/13/materia.2009-11-13.0174795645/view [accessed 16 November 2009].

Lamounier, B. (1980) Voto de desconfiança: eleições e mudança na política no Brasil, 1970-1979. Vozes: Petrópolis.

Lima, L. (2009) OAB critica Jobim por reagir à criação de comissão para investigar ditadura militar. [WWW document]. URL http://www.agenciabrasil.gov.br/noticias/2009/12/30/ materia.2009-12-30.8957611310/view [accessed 6 January 2010].

Lima, L. (2010) Vannuchi: comissão da verdade não é contra as forças armadas. [WWW document]. URL http://www.agenciabrasil.gov.br/noticias/2010/01/01/materia.2010-01-01. 1792942532/view [accessed 6 January 2010].

Memórias Reveladas (2009) [WWW document]. URL http://www.memoriasreveladas.gov.br/ cgi/cgilua.exe/sys/start.htm [accessed 30 September 2009].

Mendes, V. (2010) Projeto sobre direitos humanos fica pronto em maio. [WWW document]. URL http://www.estadao.com.br/noticias/nacional,projeto-sobre-direitos-humanos-ficapronto-em-maio,535741,0.htm [accessed 10 April 2010].

Passarinho, J. (1995) 'Espaço aberto'. O Estado de São Paulo, 25 October, 8.

Pimentel, M. A. S. E. C. (2008) Lula vai arbitrar decisão da AGU em processo contra excoronel Brilhante Ustra. [WWW document]. URL http://www.agenciabrasil.gov.br/notici as/2008/10/31/materia.2008-10-31.1035024226/view [accessed 9 November 2009].

Pinacoteca do Estado de São Paulo (2009) Memorial da Resistência. [WWW document]. URL http://www.pinacoteca.org.br/?pagid=memorial_da_resistencia [accessed 28 October 2009].

Ridenti, M. (2004) 'Resistência e mistificação da resistência armada contra a ditadura: armadilhas para pesquisadores' in D. Aarão Reis, M. Ridenti and R. P. Sá Motta (eds.) O golpe e a ditadura militar: 40 anos depois (1964-2004). EDUSC: Bauru, 53-64.

Rolim, M. (2010) O jornalismo derrotado. [WWW document]. URL http://www.observatorio daimprensa.com.br/artigos.asp?cod=572CID003 [accessed 12 March 2010].

Rosenfeld, G. D. (2009) 'A Looming Crash or a Soft Landing? Forecasting the Future of the Memory "Industry"'. The Journal of Modern History 81: 122-158.

Santos, C. M., Teles, E., and Teles, J. A. (2009) Desarquivando a ditadura: memória e justiça no Brasil, Vols I and II. Aderaldo and Rothschild Editores: São Paulo.

Secretaria Especial dos Direitos Humanos da Presidência da República (SEDH) (2007) Direito à memória e à verdade: comissão especial sobre mortos e desaparecidos políticos. [WWW 
document]. URL http://www.presidencia.gov.br/estrutura_presidencia/sedh/mortosede sap/id_livro/ [accessed 11 November 2009].

Skidmore, T. (1991) Brasil: de Castelo a Tancredo, 1964-1985. Paz e Terra: Rio de Janeiro. Smith, A.-M. (1997) A Forced Agreement: Press Acquiescence to Censorship in Brazil. University of Pittsburgh Press: Pittsburgh.

Soares, G. A. D., and D’Araújo, M. C., (eds.) (1994) 21 anos de regime militar balanços e perspectivas. Editora Fundação Getúlio Vargas: Rio de Janeiro.

Souza, J. D. (2009) Maioria absoluta acha que o país piorou. [WWW document]. URL http://almanaque.folha.uol.com.br/ditadura_27mar1994_josias_de_souza.htm [accessed 15 November 2009].

Teles, J. D. A. (2009) Der folterer auf der anklagebank. [WWW document]. URL www. goethe.de/humboldt [accessed 28 October 2009].

Veja (2009) 'Memórias Reveladas'. Veja 2133(42): 30-31.

Veja (2010) 'Coisa de maluco'. Veja 2147(2): 64.

Zaverucha, J. (1994) Rumor de sabres: tutela militar ou controle civil? Ática: São Paulo.

\section{Interviews}

Anonymous (2007) Rio de Janeiro, 12 October.

Caitano, F. (2007) Rio de Janeiro, 19 July.

Cleofas (2007) Rio de Janeiro, 17 September.

Corrêa, R. (2007) Rio de Janeiro, 8 September.

Dalva (2007) Rio de Janeiro, 31 August.

Ferreira, J. (2007) Rio de Janeiro, 8 October.

João (2007) Rio de Janeiro, 18 July.

Pinto, J. (2007) Rio de Janeiro, 19 July.

Santos, C. (2007) Rio de Janeiro, 7 September.

Souza, R. (2007) Rio de Janeiro, 3 October.

Tereza (2007) Rio de Janeiro, 23 July. 